\section{Amylin and hypertension: the status of the current debate}

Dear Sir,

In response to a letter from Drs Young, Kolterman and Hall [1] published in your journal recently, we would like to emphasise the following points on a possible role for amylin in essential hypertension.

Blood pressure is controlled by a large number of vasodilators and constrictors. The actions of these vasoactive hormones are directed to the maintenance of vascular tone to avoid major changes in systemic blood pressure. It is likely that essential hypertension is not due to short-term changes in response to vasoactive hormones but instead to maladaptive changes to these stimuli over a longer period.

Young and colleagues [1] argue that although short-term treatment with amylin stimulates plasma renin activity in humans [2,3] and rats [2, 4] longer term infusion of the peptide agonist does not alter blood pressure in humans. Therefore these authors conclude, amylin plays no part in hypertension. Caution should be used, however, in drawing such conclusions based on limited data in short-term studies. Indeed in this context, it is well established that the arterial baroceptor reflex plays a central part in the short-term (minutes to hours) regulation of blood pressure. Infusion of catecholamines which mediate this reflex also has, however, no pronounced effect on blood pressure. These compounds have been a major target for antihypertensive therapy. It should be appreciated that the basis of events leading to essential hypertension are poorly understood and most probably involve profound changes in metabolism and tissue remodelling.

Our own group has investigated the relation between the amylin and renin-angiotensin systems (RAS) in the kidney particularly within several models of hypertension [5, 6]. These studies suggest an interplay between these two hormone systems at least within proximal tubules. In particular we hypothesise that the activation of the renal amylin receptor plays a central part in the development of hypertension through activation of the local RAS. It is not clear what effect, if any, infusion of amylin analogues (peptide or non-peptide) might have on these activation processes. In the normotensive subjects, because the renal amylin receptor seems to be one coupled to G-proteins, it is likely that infusion of these peptides at high concentrations will normally suppress activity as a result of deactivation or internalisation of the receptor or both, assuming sustained efficacy of the peptides.
The role of amylin as a renal growth factor [7] could also be particularly relevant. What are its long-term effects? Do its actions lead to renal remodelling which is known to be important in the development of hypertension? Preliminary data from our group suggest renal ultrastructural abnormalities in the amylin gene-deletion mouse [8].

A negative response to alterations in blood pressure after short-term infusion of peptides does not in itself provide evidence, one way or the other, for the involvement of the corresponding hormonal system in the development of hypertension. We view the issues raised above to be important when considering the possible involvement of components of the amylin system in diseases such as hypertension.

Yours sincerely,

P. Wookey and M. Cooper

\section{References}

1. Young A, Kolterman O, Hall J (1999) Amylin innocent in essential hypertension? Diabetologia 42: 1029

2. Young AA, Rink TJ, Vine W, Gedulin B (1994) Amylin and syndrome X. Drug Dev Res 32: 90-99

3. Cooper ME, McNally PG, Phillips PA, Johnston CI (1995) Amylin stimulates plasma renin concentrations in humans. Hypertension 26: 460-464

4. Wookey PJ, Tikellis C, Du H-C, Qin H-F, Sexton PM, Cooper ME (1996) Amylin binding in the renal cortex, stimulation of adenylyl cyclase and activation of plasma renin. Am J Physiol 270: F289-F294

5. Wookey PJ, Cao Z, van Geenen RCI, Voskuil M, Darby IA, Komers R, Cooper ME (1997) Increased density of renal amylin binding sites in experimental hypertension. Hypertension 30: 455-460

6. Wookey PJ, Cao Z, Cooper ME (1998) Interaction of the renal amylin and renin-angiotensin systems in animal models of diabetes and hypertension. Miner Electrolyte Metab 24: 389-399

7. Wookey PJ, Tikellis C, Nobes M, Casley D, Cooper ME, Darby IA (1998) Amylin as a growth factor during foetal and postnatal development of the rat kidney. Kidney Int 53: $25-30$

8. Wookey PJ, Xuereb L, Alcorn D, Parkes D, Devine E, Young A, Cooper ME (1999) Renal pathology associated with the postnatal mouse: the amylin gene-deletion model. J Am Soc Nephrol 10: 413A (Abstract)
Corresponding author: P. J. Wookey, Department of Medicine, University of Melbourne, Austin \& Repatriation Medical Centre, Repatriation Campus, Heidelberg West, Victoria 3081, Australia 